\title{
Journal of the Scholarship of Teaching and Learning for Christians in Higher Education
}

Volume 9 | Issue 1

Article 3

2019

\section{Editorial}

Hayoung Lim

Oral Roberts University, hlim@oru.edu

Follow this and additional works at: https://digitalshowcase.oru.edu/sotl_ched

Part of the Christianity Commons, and the Scholarship of Teaching and Learning Commons

\section{Recommended Citation}

Lim, H. (2019). Editorial. Journal of the Scholarship of Teaching and Learning for Christians in Higher Education, 9(1), 1-3. https://doi.org/ 10.31380/sotlched.9.1.1

This Editorial is brought to you for free and open access by Digital Showcase. It has been accepted for inclusion in Journal of the Scholarship of Teaching and Learning for Christians in Higher Education by an authorized editor of Digital Showcase. For more information, please contact digitalshowcase@oru.edu. 


\section{EDITORIAL}

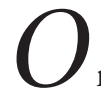

n Sunday, March 11, 2019, a Boeing 737 MAX 8, which was a variant of the world's most popular jetliner, crashed in Ethiopia, killing all 150 passengers and crew on board. In October 2018, another MAX 8 had crashed in Indonesia, killing all 157 people on board. The terrible accidents within six months of each other-both sharing some similar equipment failures-have raised critical questions about the airplane's automated systems involving very advanced and complicated technologies. Many news reports and experts have maintained that the airline industry is relying too much on overly complex automation systems, and at least half a dozen pilots have complained about experiencing unexpected nosedives set in motion from the automation. Many people contend that there are some obvious downsides to technology as it gets more and more complex. "Techlash," a blend of "technology" and "backlash," is one of the growing issues regarding technology and the dominant high-tech companies versus the negativity of their users. According to the Oxford dictionary, "techlash" is defined as a strong and widespread negative reaction to the growing power and influence of the large (i.e., dominant) technology companies.

In facing the current phenomena relating to technology in our daily lives, teachers inevitably look for ways to apply technology in teaching and learning. Benefits of using technology in the classroom have been abundantly reported and verified: increased student engagement, equal learning opportunities, networking capacity, easy access to resources, and improved productivity in academics. However, disadvantages of using high-tech mechanization and highly advanced technologies in education have also been greatly reported, and these problems usually consist of deeper inquiries in learning, such as (1) a lack of transforming knowledge (i.e., merely presenting information via technology without proper pedagogical planning can prevent information from being transformed into a larger schemata); (2) a declining value of teaching (i.e., 
disregarding care for individuals, ignoring emotional needs, and not addressing the whole person prevents a beneficial relationship between teacher and student); (3) depersonalization (i.e., not connecting the individual person and the user of technology depersonalizes the learning experience); (4) confused or misled self-efficacy (i.e., overusing technology may cause students to inaccurately assessing their own academic performance); and (5) superficial achievements (i.e., relying too much on technology may not accurately reveal students' true achievements and may not through. The current generation of students does not have the privilege of choosing the role of technology in their education by considering these advantages and disadvantages. Has this generation ever agreed to have this level of technology in their lives? Social engineering and technical developments are flying toward future without the future generation's consent.

The most critical problems from developing technologies might be the excessive level of dependence on and superfluity of technology. Overabundance always brings deficiency. Technology can construct the optimal learning environment; meanwhile, it can demolish the divine structure of human learning. The Apostle Peter wrote, "For this very reason, make every effort to add to your faith, goodness; and to goodness, knowledge; and to knowledge, self-control [moderation]; and to self-control, perseverance, and to perseverance to godliness ..." (2 Peter 1:5-7). Self-control is one of the greatest fruits of Holy Spirit, and if we possess this quality, it will make us effective and productive in the knowledge of our Lord Jesus Christ. We Christian educators must adhere to this particular fruit of the Holy Spirit and seek a balance in using various technologies in our practice.

Oral Roberts University has developed and established a Global Learning Center (GLC) that is equipped with the most advanced learning technologies, including virtual reality and augmented reality technologies. The GLC provides the greatest learning experiences and accessibility to the most updated learning resources for students from any continent in the world. We should not only celebrate achievements in technology but also continue monitoring how to best use technology in learning environments for our students; we should not overuse or misuse technology because it is fascinating and easily available. The 
quality of moderation and discernment would produce many advantages for the use of technologies in Holy Spirit empowered teaching and learning.

$\mathcal{H}$ ayoung $\mathcal{L}$ im

General Editor 
